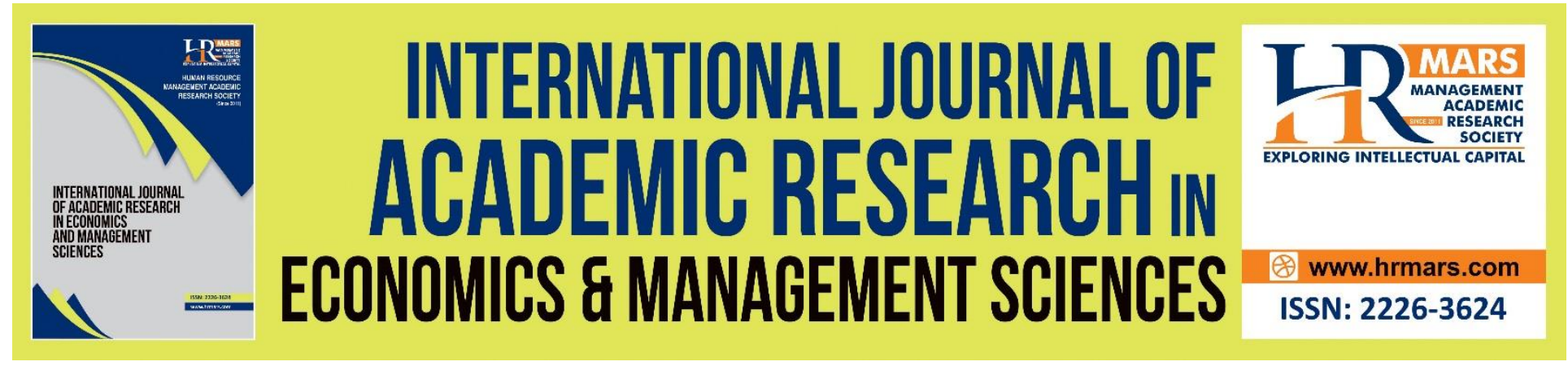

\title{
Driving Relationship Marketing Tactics towards Customer Loyalty Building: The Mediating Effect of Commitment and Trust
}

Lennora Putit, Mohamad Fariz Abdullah, Amirah Ahmad Suki

To Link this Article: http://dx.doi.org/10.6007/IJAREMS/v10-i1/9655

DOI:10.6007/IJAREMS/v10-i1/9655

Received: 22 January 2021, Revised: 28 February 2021, Accepted: 16 March 2021

Published Online: 30 March 2021

In-Text Citation: (Putit et al., 2021)

To Cite this Article: Putit, L., Abdullah, M. F., \& Suki, A. A. (2021). Driving Relationship Marketing Tactics towards Customer Loyalty Building: The Mediating Effect of Commitment and Trust. International Journal of Academic Research in Economics and Managment and Sciences, 10(1), 170-188.

Copyright: (C) 2021 The Author(s)

Published by Human Resource Management Academic Research Society (www.hrmars.com)

This article is published under the Creative Commons Attribution (CC BY 4.0) license. Anyone may reproduce, distribute, translate and create derivative works of this article (for both commercial and non-commercial purposes), subject to full attribution to the original publication and authors. The full terms of this license may be seen at: http://creativecommons.org/licences/by/4.0/legalcode

Vol. 10, No. 1, 2021, Pg. 170 - 188

http://hrmars.com/index.php/pages/detail/IJAREMS

JOURNAL HOMEPAGE

Full Terms \& Conditions of access and use can be found at http://hrmars.com/index.php/pages/detail/publication-ethics 


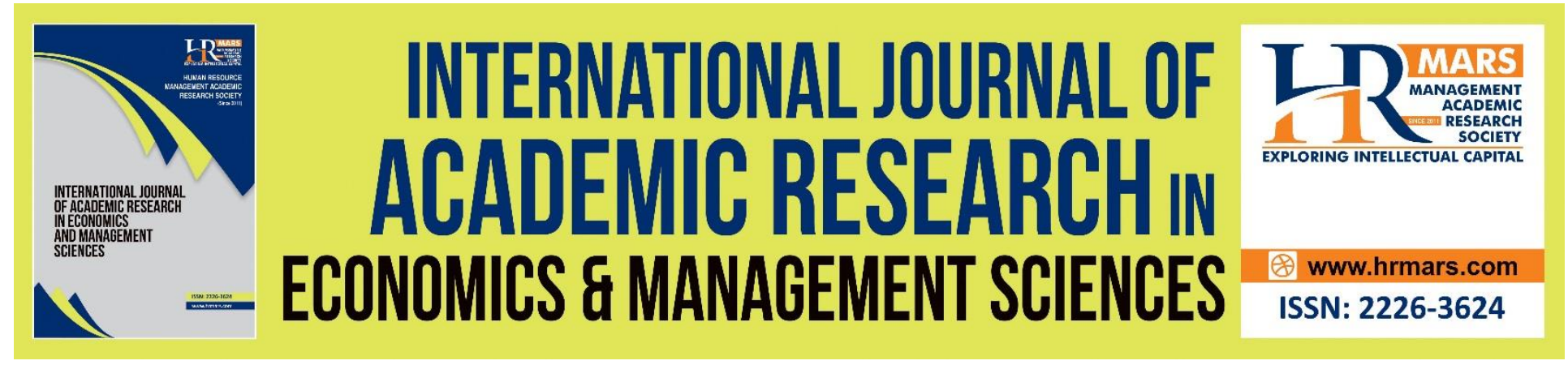

\title{
Driving Relationship Marketing Tactics towards Customer Loyalty Building: The Mediating Effect of Commitment and Trust
}

\author{
${ }^{1}$ Lennora Putit, ${ }^{2}$ Mohamad Fariz Abdullah, ${ }^{3}$ Amirah Ahmad Suki \\ ${ }^{1,2}$ Faculty of Business and Management, Universiti Teknologi MARA, Puncak Alam 42300, \\ Selangor, Malaysia, ${ }^{3}$ Kulliyah of Economics and Management Sciences, International Islamic \\ University Malaysia, Gombak 53100, Selangor, Malaysia
}

\begin{abstract}
One of the main targets in relationship marketing is to ensure continued retention of profitable customers by building on and sustaining a stable long-term relationship that will subsequently result in customer loyalty behavior. This study focuses on relationship marketing tactics (RMT) dimensions of brand reputation and trust and how it influences customer loyalty, as well as examining the mediating effects of relationship quality (RQ) of commitment and trust within the context of a competitive mobile telecommunication service industry. Using quota sampling approach, a total of 382 survey questionnaires' usable feedback were collected from targeted respondents for data analyses. A quantitative analytical method was applied via SPPS version 20.0 and a PLS-SEM software procedure using Smart PLS version 3.0 with bootstrapping analysis to test the developed hypotheses. Hypothetical results revealed differential effects of RMT on customer loyalty. Brand reputation significantly influenced both commitment and trust. Alternative attractiveness also significantly affected commitment and trust. The mediating effects of RQ further revealed the continued importance of commitment and trust as key factors in developing a successful customer loyalty. Several theoretical and managerial implications are further discussed.
\end{abstract}

Keywords: Relationship Marketing, Marketing Tactics, Brand Reputation, Alternative Attractiveness, Commitment, Trust, Customer Loyalty.

\section{Introduction}

In marketing, service providers' continuous need to better understand their customers has ascended as a result of numerous factors such as aggressive market competition, dynamic and complex environment, consumers' increased expectation, and rapid innovation in the service industry (Sheth, 2017; Kazemifar \& Shayesteh, 2015). Nowadays, service providers are likely to explore more about their customers in an attempt to retain them and create customer loyalty. This in turn, will further increase their business profits. Since the concept of relationship 
marketing has become a fundamental focus in the service sector nowadays, many marketing tactics has been implemented by the service providers to create successful long-term relationship with their customers (Akrout \& Nagy, 2018). Nevertheless, no matter how excellent the services are being delivered, most service providers are still unsuccessful in meeting the expectations of today's demanding customers (Bianci \& Abu Saleh, 2020; Nikbin, Ismail \& Marimuthu, 2012). To compete in such a crowded and interactive market environment, service providers are obliged to move forward beyond the traditional marketing (4P's), as the method is no longer relevant towards achieving a competitive advantage (Dithan, 2011). As such, relationship marketing has become an additional resource for business organizations in order to establish a solid, ongoing association with their customers.

Bansal, Taylor \& James (2005) has pointed out the importance of relationship marketing by elaborating twelve antecedents that include quality, satisfaction, value, trust, price perception, commitment, alternative attractiveness, attitude towards switching, subjective norms, switching costs, prior switching experience and variety seeking. This study explores the applicability of the Push Pull Mooring Migration Model in relation to factors influencing customers' switching behaviour. Ever since the model's inception, many researchers attempt to adopt these factors related to relationship marketing and customer loyalty in their respective research studies (e.g. Tseng, 2007; Ghasemi et.al, 2013; Abdullah, Teo \& Putit, 2014; Putit \& Abdullah, 2019).

Meanwhile, Palmatier (2008) claimed that The Commitment-Trust Theory of Relationship Marketing model developed by Morgan and Hunt (1994) could be considered as one of the most influential theories in relationship marketing practice. The theory emphasized on the presence of commitment and trust as keys to a successful relationship marketing despite occurrences of many other contextual elements that influence the success or failure in relationship marketing. Once both commitment and trust are present, they can produce outcomes which can encourage efficiency, productivity, and effectiveness, hence, lead directly to a successful relationship marketing (Morgan \& Hunt, 1994). Consequently, both trust and commitment play important mediating roles in strengthening customer loyalty (van Tonder, 2017; Akrout \& Nagy, 2018). Following the aforementioned arguments, this paper attempts to address these challenges by examining the influence of relationship marketing tactics (RMT) on relationship quality (RQ) and customer loyalty. This is undertaken by proposing two tactics namely, brand reputation and alternative attractiveness; and the influences of relationship quality that comprises of commitment and trust as mediating variables towards customer loyalty within the mobile telecommunication industry.

\section{Literature Review and Hypotheses Development \\ Relationship between Brand Reputation and Relationship Quality}

A strong reputation can offer many advantages to firms such as repeat purchases and recommendations of the brand to friends and relatives (Foroudi, 2019). This is because a vigorous brand reputation can increase customer trust, provide a better understanding into intangible products, and reduces customer's buying risk (Sengupta, Balaji \& Krishnan, 2015; Agmeka et. al., 2019). Moreover, a service provider with forceful brand reputation tends to lessen the customer's switching behaviour over a certain time period. When a customer perceives that his/her friends or relatives are of the opinion that a brand has a good reputation, the customer may trust the brand sufficiently to pay for it (Ryan \& Casidy, 2018). Cheng et al. (2008) viewed 
that a firm's brand reputation is projected by the firm in the mind of its customers based on their experience, word of mouth and advertising.

Other studies have also discovered brand reputation as a related factor that helps to build customer loyalty, trust and commitment from the customers with their existing service providers (Segupta et. al, 2015; Ryan \& Cassidy, 2018; Foroudi, 2019). However, these studies did not contrast the relative impact of brand reputation with other relationship marketing tactics; even though they have provided empirical evidence linking brand reputation or reputation-related beliefs to attitude toward switching (Peng \& Wang, 2007). Therefore, a strong brand reputation is supposed to meet customer's expectation and present more benefits to the customer, as a result leading to customer trust and commitment. Following that, this study attempts to measure the influence of brand reputation on the Malaysian mobile telecommunication sector by proposing the following hypotheses:

H1a: Brand Reputation has a positive significant influence on Commitment in the mobile telecommunication industry.

H1b: Brand Reputation has a positive significant influence on Trust in the mobile telecommunication industry.

\section{Relationship between Alternative Attractiveness and Relationship Quality}

Mannan, Mohiuddin, Chowdhury \& Sarker (2017), claimed that the higher the customers were alerted about the alternative attractiveness of competing service providers, the higher the likelihood that they will choose not to be loyal to their current service providers due to the availability of other options. This argument is widely held by many researchers (Lee, Ou, \& Choi, 2021; Bashir, 2011; Yen \& Horng, 2010; Bansal et al, 2005). Nevertheless, each researcher pointed out different views of the relationship between alternative attractiveness and customer loyalty. Lee et al (2021); Sharma \& Patterson (2000) stated that a weak alternative attractiveness offering can affect the likelihood of a customer to either stay loyal or to switch their service providers. Customers may decide to end the relationship and turn to a new service provider if they recognize the alternative to be attractive due to the availability of superior service, the proximity of location, the availability of a full range service, lower price perception or the promise of high financial returns (trustworthy).

A different view by Yen \& Horng, (2010), insisted that alternative attractiveness is significant and negatively impacts the customer involvement in long-term relationship and relationship commitment. The authors stated that customers are committed to the service providers and tend to preserve existing relationships only if they are unconscious of alternative attractiveness or do not perceive the alternatives to be more attractive than what has current service provider's offer. Bansal et.al (2005) has suggested that alternative attractiveness can be utilized as a "pull" factor which can attract customers to stay as they are conscious of available alternatives from that existing service provider, thus, developing a customer loyalty. Therefore, this study attempts to examine the influence of alternative attractiveness, whether it can be a factor to pull them to switch to another service provider in the Malaysian mobile telecommunication sector by proposing the following hypotheses:

$\mathrm{H} 2 \mathrm{a}$ : Alternative Attractiveness has a positive significant influence on Commitment in the mobile telecommunication industry. 
INTERNATIONAL JOURNAL OF ACADEMIC RESEARCH ECONOMICS AND MANAGEMENT SCIENCES Vol. 10, No. 1, 2021, E-ISSN: 2226-3624 @ 2021 HRMARS

$\mathrm{H} 2 \mathrm{~b}$ : Alternative Attractiveness has a positive significant influence on Trust in the mobile telecommunication industry.

\section{Relationship between Relationship Quality and Customer Loyalty}

Commitment is a central concept in relationship marketing which leads to customer loyalty (Sheth, 2017; Rahman \& Ramli, 2016). Morgan \& Hunt (1994) have emphasized that commitment is an important component of a successful relationship because it gives a rise to mediate behaviour. Furthermore, commitment assists in building a long-term relationship between service providers and customers. Morgan \& Hunt (1994) considered commitment as one of the two most important factors (another factor is trust) in determining loyalty of this relationship and approach it as a synonym of customer loyalty. A commitment based on emotions has a positive impact on customer intentions (Reydet \& Carsana, 2017), and on positive verbal communication (Hennig-Thurau et al., 2002). Moreover, commitment encourages and fosters customer collaboration and loyalty (Morgan \& Hunt, 1994). Similar to trust, commitment is one of the most significant variables that aid to evaluate relationship strength level and is a useful element of loyalty measuring (Akrout and Nagy, 2018, Sheth, 2017; Rahman \& Ramli, 2016).

Trust is one of the major components of customer loyalty, to which they may buy more, accept higher prices, and develop a positive word-of-mouth communication (Akrout and Nagy, 2018; Aydin \& Ozer, 2005). Building trust between service providers and consumers will encourage them to assume that the risk which may occur in the business transactions are borne by both parties (Ahn, Shamin \& Park, 2021). If the service provider is able to keep their promises, reliable, and concern for their customers, this can then influence the customer's loyalty to that particular service provider (Anderson \& Karlstrom, 2014). The development of trust is considered to be a critical result of establishing a long-term successful relationship between all parties involved. This is due to the presence of service-based industries, as customers tend to act and make a purchase decision depending on their previous consuming experience (Ahn et al, 2021). Furthermore, customer's trust also plays a significant role in building long term relationship and achieving customer loyalty (Akrout \& Nagy, 2018; Auruskeviciene et.al, 2010). Therefore, this study attempts to measure the impact of commitment and trust to customer loyalty in the Malaysian mobile telecommunication sector by proposing the following hypothesis:

H3a: Commitment has a positive significant impact on Customer Loyalty in the mobile telecommunication industry

$\mathrm{H} 3 \mathrm{~b}$ : Trust has a positive significant impact on Customer Loyalty in the mobile telecommunication industry

\section{Relationship Quality as a Mediators between RMT's and Customer Loyalty}

It has been proposed that relationship quality could be evaluated by looking at different dimensions such as trust, communication, and interdependence (Themelin et al., 2020, Tough et al, 2018). Morgan and Hunt (1994) stated that those commitment and trust components are the basic constructs for measuring loyalty. The literature on relationship quality suggests that the quality of the relationship between the parties involved is an important determinant of loyalty (Leverin \& Liljander 2006). However, there is no consensus regarding the right relationship quality dimensions, and little empirical evidence regarding the nature and extent of the overall 
impact of relationship quality on service quality. Relationship quality dimensions may come from a variety of factors (Themelin et al., 2020; Tough et al., 2018). Akrout \& Nagy (2018) and Bianci \& Abu Saleh (2020) stated that trust, satisfaction, and commitment are indispensable elements to form a relationship quality dimension. The findings revealed that the level of trust and commitment are the most common attributes of relationship quality. High relationship quality may also result in customers' reliance on the integrity and future performance of their service provider (Nadeem et.al. 2020; Bianci \& Abu Saleh, 2020).

In this study, two variables comprising commitment and trust were proposed as relationship quality (RQ). Morgan \& Hunt (1994) has described the importance of both factors in determining customer loyalty. Commitment and trust provide values for the customers, and act as important factors towards achieving loyalty (Bianci \& Abu Saleh, 2020; Putit \& Adullah, 2019; Jesri et.al, 2013). This study attempts to measure the impact of commitment and trust as mediating factor between brand reputation and alternative attractiveness to customer loyalty in the Malaysian mobile telecommunication sector by proposing the following hypotheses:

H4a: Commitment mediates between Brand Reputation and Customer Loyalty

H4b: Commitment mediates between Alternative Attractiveness and Customer Loyalty

H4c: Trust mediates between Brand Reputation and Customer Loyalty

H4d: Trust mediates between Alternative Attractiveness and Customer Loyalty

\section{Conceptual Framework}

Theories are used with the intention of explaining the relationship between RMT, relationship quality and customer loyalty. This study has examined a few theories of customer loyalty in order to understand their relationship with RMT's. Thus, this study proposes a conceptual framework on customer loyalty in the mobile communication context based on several past theoretical reviews. The overall framework provided the basis for the research on the RMT, relationship quality and customer loyalty as depicted in figure 1.

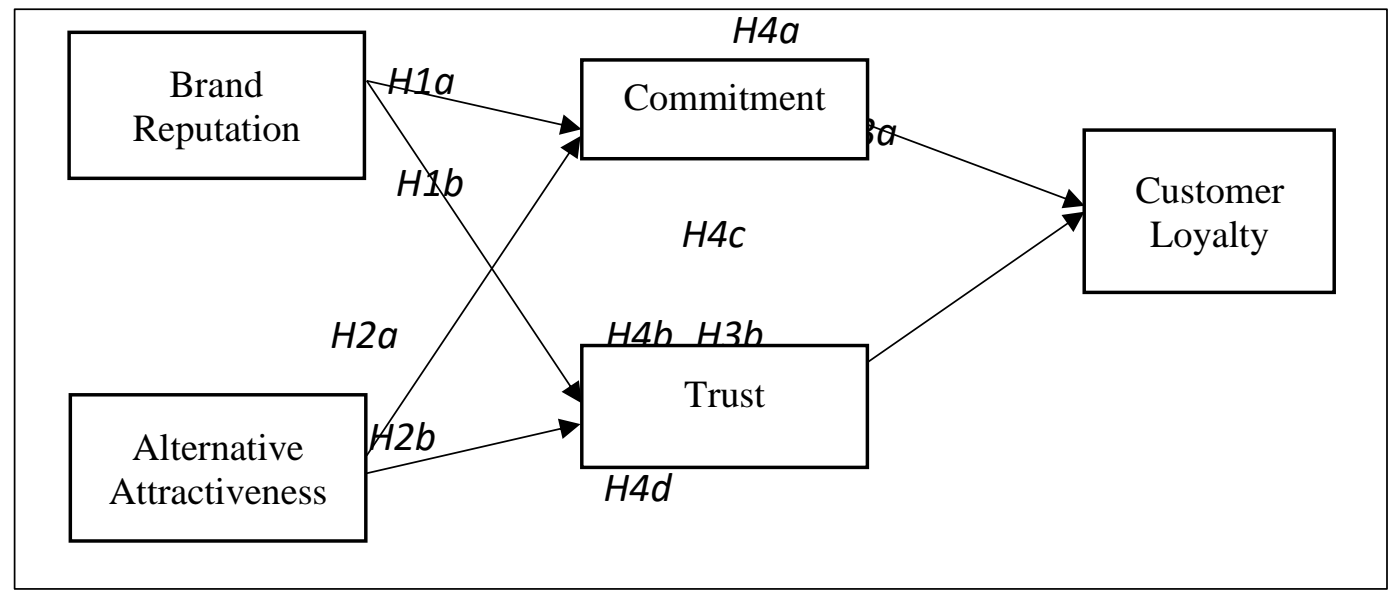

Figure 1: Conceptual Framework for the Study

\section{Methodology}

The respondents of this study were mobile phone users who subscribed to mobile service providers such as Maxis, Celcom, Digi, and U-Mobile in Peninsular Malaysia. These respondents 
were the main users of mobile networks numbering $010,011,012,013,014,016,017$, and 019 respectively. Both segments of post-paid and prepaid users were covered except for fixed home lines. Table 1 has shown the population's distribution of sample size and the determination of sample size appropriate for this study using quota sampling technique.

Table 1: Distribution of Sample Size by Quota Sampling

\begin{tabular}{lclllll}
\hline & & $\begin{array}{l}\text { Kuala } \\
\text { Lumpur }\end{array}$ & Shah Alam & $\begin{array}{l}\text { Bandaraya } \\
\text { Melaka }\end{array}$ & Penang & TOTAL \\
\hline Gender & - Male & 50 & 50 & 50 & 50 & \multirow{2}{*}{$\mathbf{4 0 0}$} \\
& Female & 50 & 50 & 50 & 50 & \\
\hline Ethnicity & - Malay & 60 & 60 & 60 & 60 & \\
& Chinese & 30 & 30 & 30 & 30 & $\mathbf{4 0 0}$ \\
& Indian & 10 & 10 & 10 & 10 & \\
\hline TOTAL & & & & & & $\mathbf{4 0 0}$ \\
\hline
\end{tabular}

A total of 400 samples were chosen for primary data collection based on the determination of sample size set by Krejcie, \& Morgan (1970). Four main cities in Peninsular Malaysia that included Kuala Lumpur, Shah Alam, Melaka, and Penang were selected since they revealed the highest mobile phone rate users compared to other cities (MCMC, 2014).

The survey questionnaire's instrument details involved targeted respondents' demographic profile, and item scales of brand reputation, alternative attractiveness, commitment, trust, and customer loyalty. A set of self-administered questionnaires was developed consisting of 27 items. This set of questionnaires comprised seven (6) sections: Section A: Demographic profile, Section B: Brand reputation, Section C: Alternative Attractiveness, Section D: Commitment, Section E: Trust and lastly Section F: Customer loyalty. A multi-items scale was engaged in order to measure the variables, which was adopted and adapted from the previous literature as presented in Table 2. 
INTERNATIONAL JOURNAL OF ACADEMIC RESEARCH ECONOMICS AND MANAGEMENT SCIENCES Vol. 10, No. 1, 2021, E-ISSN: 2226-3624 @ 2021 HRMARS

Table 2: Sources and Reliability of the Construct Used in the Study

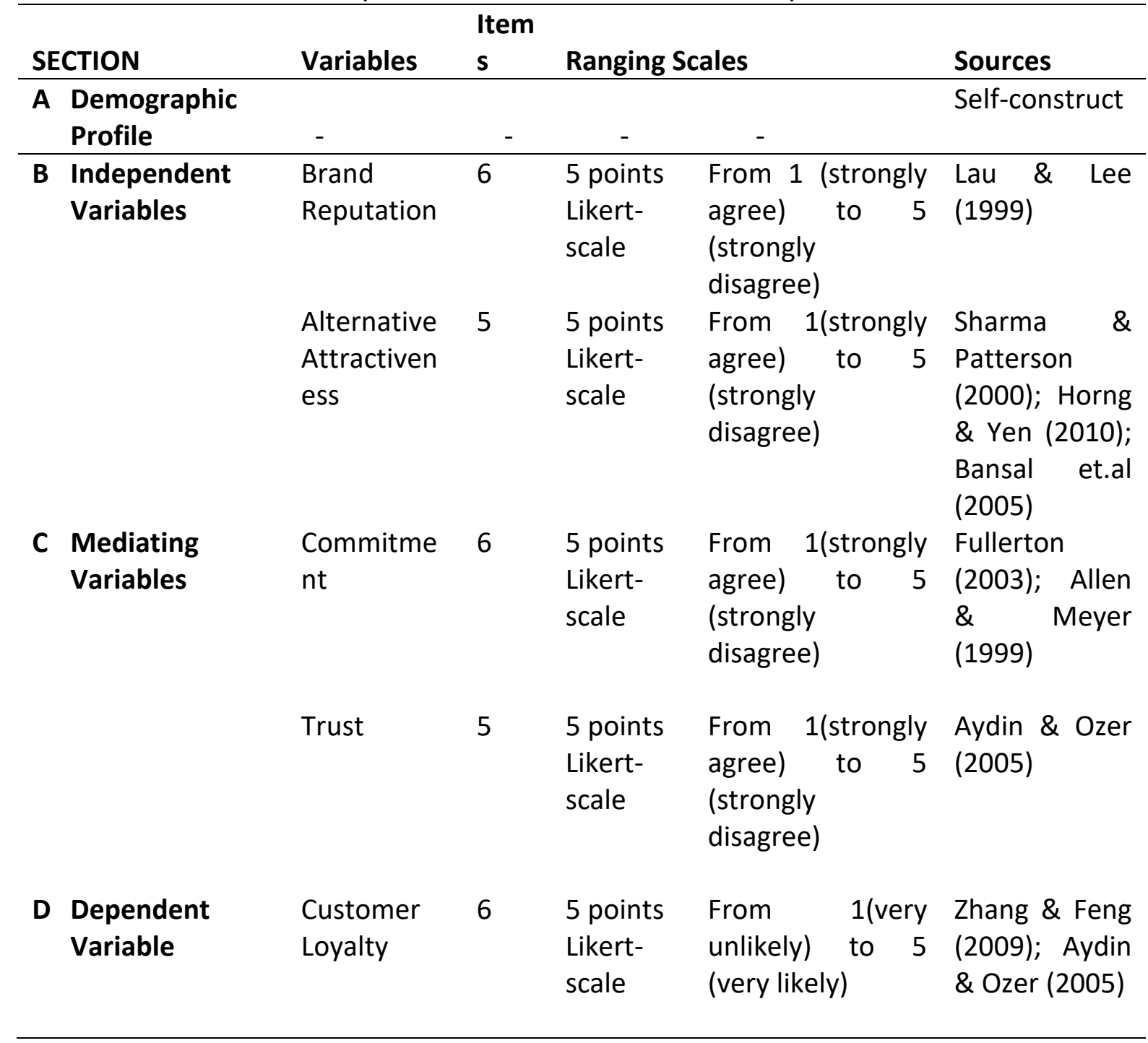

In the demographic profile section, this study has followed recommendations set by Malaysian Communication and Multimedia Commission Hand Phone User Survey (MCMC 2014, pp 7), to which the data were collected by both core set and trends set. The core set includes nationality (only Malaysian citizen), sex (male and female), ethnicity (Malay, Chinese, Indian, and others), age group, level of education, and income level. Meanwhile, for the trend set, this study has included the length of usage of the mobile services. Each item in the questionnaire was measured using five point Likert-scale ranging from 1 = "Strongly disagree" to $5=$ "Strongly agree" to measure the questionnaire as it is simple to construct, likely to produce a highly reliable scale and easy to read and complete for participants (Malhotra, 2009).

A pilot study was initiated to check on the item reliability, with Cronbach's Alpha value above 0.70. According to Churhill \& lacobucci (2005), the instruments should be reviewed to ensure an absence of confusion, offensiveness or misleading of survey questionnaire. In addition, it can assist researchers to identify mistakes on the survey questionnaires such as wording, sequence, form and layout, difficulty, and instructions for a better understanding before actual survey is 
carried out (Peng, 2006). Bernard (2000) suggested an observation of at least 6 to 10 respondents in a pilot study. In this study, a pilot test was done on a convenient sample of 30 mobile phone users.

\section{Data Analysis}

A total of 395 returned questionnaires were checked, decoded, and keyed into the database using statistical software SPSS Version 20 and Smart PLS 3.0 software. Data screening processes were performed by preliminary check and data cleaning procedures to search out for legibility, consistency, competency, and ambiguity of the responses. Based on the preliminary checks, 3 questionnaires were discarded because they are returned as blanks, while another 10 questionnaires were discarded with over $30 \%$ of unanswered items in the total response (e.g., not answering certain part in the questionnaire booklet).

The study has performed a partial least square structural equation modelling to test the relationship of brand reputation and alternative attractiveness on relationship quality, and the relationship of relationship quality on customer loyalty as projected in hypotheses $\mathrm{H} 1 \mathrm{a}, \mathrm{H} 1 \mathrm{~b}, \mathrm{H} 2 \mathrm{a}$, $\mathrm{H} 2 \mathrm{a}, \mathrm{H} 3 \mathrm{a}$, and $\mathrm{H} 3 \mathrm{~b}$. However, since the remaining hypotheses: $\mathrm{H} 4 \mathrm{a}, \mathrm{H} 4 \mathrm{~b}, \mathrm{H} 4 \mathrm{c}$, and $\mathrm{H} 4 \mathrm{~d}$ requires examining the effect of mediating variables, mediation analyses were conducted for testing the mediating role of commitment and trust, using the bootstrapping method of Preacher and Hayes (2008). For this study, 5000 bootstrap resamples were chosen with $95 \%$ confidence interval (CI) of the indirect effects by following recommendation from Preacher \& Hayes (2008).

\section{Findings}

A total of 382 usable survey questionnaires were carried out for further statistical analysis. The demographic profile of respondents' data was identified by performing the frequencies analysis as presented in Table 3. 
Table 3: Frequencies Analysis

\begin{tabular}{|c|c|c|}
\hline Variables & Frequencies & Percentages (\%) \\
\hline \multicolumn{3}{|l|}{ Age group: } \\
\hline 21 to 24 years' old & 158 & $41.5 \%$ \\
\hline 25 to 29 years' old & 106 & $27.7 \%$ \\
\hline 30 to 34 years' old & 72 & $18.8 \%$ \\
\hline 35 years old and above & 46 & $12 \%$ \\
\hline \multicolumn{3}{|l|}{ Gender: } \\
\hline$\overline{\text { Male }}$ & 198 & $51.8 \%$ \\
\hline Female & 184 & $48.2 \%$ \\
\hline \multicolumn{3}{|l|}{ Race: } \\
\hline Malay & 226 & $59.2 \%$ \\
\hline Chinese & 116 & $30.4 \%$ \\
\hline Indian & 40 & $10.4 \%$ \\
\hline \multicolumn{3}{|l|}{ Education: } \\
\hline Bachelor's degree & 227 & $59.4 \%$ \\
\hline Master & 27 & $7.1 \%$ \\
\hline PhD & 1 & $0.3 \%$ \\
\hline Others & 127 & $33.2 \%$ \\
\hline \multicolumn{3}{|l|}{ Income: } \\
\hline Less than RM 1000 & 121 & $31.7 \%$ \\
\hline RM 1000 to RM 3000 & 158 & $41.4 \%$ \\
\hline RM 3000 to RM 5000 & 76 & $19.9 \%$ \\
\hline RM 5000 and above & 27 & $7 \%$ \\
\hline \multicolumn{3}{|l|}{ Operator: } \\
\hline Maxis & 176 & $46.1 \%$ \\
\hline Celcom & 109 & $28.5 \%$ \\
\hline Digi & 71 & $18.6 \%$ \\
\hline Others & 26 & $6.8 \%$ \\
\hline \multicolumn{3}{|l|}{ Time: } \\
\hline Less than 1 year & 27 & $7 \%$ \\
\hline 1 to 4 years & 154 & $40.3 \%$ \\
\hline 5 to 9 years & 163 & $42.7 \%$ \\
\hline 10 years and above & 38 & 10 \\
\hline
\end{tabular}

\section{Measurement and Structural Model}

In assessing the measurement model, both convergent validity and discriminant validity have been used. The convergent validity of the measurement is usually ascertained by reviewing the loadings, average variance extracted and also the composite reliability (Gholami et al., 2013). The result here shows that 5 items were deleted due to low loadings. The loadings should be greater than 0.7 to ensure validity of the item. A total of 22-item then measured for composite reliability where all the values were greater than 0.7 , and the AVE values were also greater than 0.5 as shown in Table 4 below. 
INTERNATIONAL JOURNAL OF ACADEMIC RESEARCH ECONOMICS AND MANAGEMENT SCIENCES Vol. 10, No. 1, 2021, E-ISSN: 2226-3624 @ 2021 HRMARS

Table 4: Convergent validity

\begin{tabular}{|c|c|c|c|c|}
\hline Construct & Item & Loadings & AVE & $\mathrm{CR}$ \\
\hline \multirow[t]{5}{*}{ Brand Reputation } & BR1 & 0.813 & 0.620 & 0.891 \\
\hline & $\mathrm{BR} 2$ & 0.783 & & \\
\hline & BR3 & 0.819 & & \\
\hline & BR4 & 0.768 & & \\
\hline & BR5 & 0.752 & & \\
\hline \multirow[t]{3}{*}{ Alternative Attractiveness } & AA1 & 0.744 & 0.684 & 0.866 \\
\hline & AA2 & 0.865 & & \\
\hline & AA3 & 0.867 & & \\
\hline \multirow[t]{6}{*}{ Commitment } & CM1 & 0.710 & 0.564 & 0.886 \\
\hline & $\mathrm{CM} 2$ & 0.772 & & \\
\hline & $\mathrm{CM} 3$ & 0.730 & & \\
\hline & CM4 & 0.796 & & \\
\hline & CM5 & 0.752 & & \\
\hline & CM6 & 0.743 & & \\
\hline \multirow[t]{4}{*}{ Trust } & TR1 & 0.823 & 0.675 & 0.892 \\
\hline & TR2 & 0.795 & & \\
\hline & TR4 & 0.827 & & \\
\hline & TR5 & 0.840 & & \\
\hline \multirow[t]{4}{*}{ Customer Loyalty } & CL1 & 0.799 & 0.656 & 0.884 \\
\hline & CL2 & 0.759 & & \\
\hline & CL5 & 0.815 & & \\
\hline & CL6 & 0.863 & & \\
\hline
\end{tabular}

*Note: AA1, AA3, TR3, CL3 and CL4 were deleted due to low loadings

The discriminant validity of the measures criteria has been used in comparing the correlations between constructs and the square root of the average variance extracted for that construct. Table 5 below shows that all the values on the diagonals were greater than the corresponding row and column values indicating that the measures were discriminant. 
Table 5: Discriminant Validity

\begin{tabular}{llllll}
\hline & $\begin{array}{l}\text { Alternative } \\
\text { Attractiven } \\
\text { ess }\end{array}$ & $\begin{array}{l}\text { Brand } \\
\text { Reputatio } \\
\mathrm{n}\end{array}$ & Commitment & $\begin{array}{l}\text { Customer } \\
\text { Loyalty }\end{array}$ & Trust \\
\hline $\begin{array}{l}\text { Alternative } \\
\text { Attractiveness }\end{array}$ & $\mathbf{0 . 8 2 7}$ & & & & \\
$\begin{array}{l}\text { Brand } \\
\text { Reputation }\end{array}$ & 0.658 & $\mathbf{0 . 7 8 8}$ & & & \\
$\begin{array}{l}\text { Commitment } \\
\text { Customer }\end{array}$ & 0.632 & 0.632 & $\mathbf{0 . 7 5 1}$ & & \\
$\begin{array}{l}\text { Loyalty } \\
\text { Trust }\end{array}$ & 0.617 & 0.627 & 0.688 & $\mathbf{0 . 8 1 0}$ & \\
\hline
\end{tabular}

Note: Values on the diagonal (bolded) are square root of the AVE while the off diagonals are correlations

\section{Relationship between RMT's And Relationship Quality (Hypotheses H1a, H1b, H2a, And H2b)} Structural modelling procedure was executed to test the relationship between brand reputation and alternative attractiveness with commitment (outcome variable) (Hypotheses $\mathrm{H} 1 \mathrm{a}$ \& $\mathrm{H} 2 \mathrm{a}$ ). The results show that $R^{2}=0.482$, indicating that a total of $48.2 \%$ variance of commitment is explained by brand reputation and alternative attractiveness. Both predictors contributed a significant impact on commitment, where the strongest predictor is brand reputation $(\beta=0.382$, $p<0.05)$ followed by alternative attractiveness $(\beta=0.380, p<0.05)$ respectively. Meanwhile, the relationship between brand reputation and alternative attractiveness with the trust (outcome variable) (Hypotheses $\mathrm{H} 1 \mathrm{~b} \& \mathrm{H} 2 \mathrm{~b}$ ) shows the value of $\mathrm{R}^{2}=0.508$, hence indicating that almost $50.8 \%$ variability of trust as a dependent variable, can be explained by its predictors, that is, brand reputation and alternative attractiveness. Both predictors contribute a significant impact on trust, and that the strongest predictor comes from alternative attractiveness $(\beta=0.53, p<0.05)$ followed by brand reputation $(\beta=0.327, p<0.05$ ) respectively. Therefore, $\mathrm{H} 1 \mathrm{a}, \mathrm{H} 1 \mathrm{~b}, \mathrm{H} 2 \mathrm{a}$, and $\mathrm{H} 2 \mathrm{~b}$ are supported in this study.

\section{Relationship between Relationship Quality and Customer Loyalty (Hypotheses H3a and H3b)} In order to analyse the relationship between the relationship quality (comprising of commitment and trust) with the dependent variable, customer loyalty, $\mathrm{R}^{2}$ value appears to be 0.523 . This indicates that a total of $52.3 \%$ variability of customer loyalty is explained by both commitment and trust. The result also establishes that commitment and trust contribute significant impacts on the dependent variable, customer loyalty with commitment appearing to be the strongest predictor $(\beta=0.443, p<0.05)$ followed by trust $(\beta=0.330, p<0.05)$ respectively. In this equation, trust appears to be the strongest influence on customer loyalty compared to commitment with a beta value of 0.464 . Table 6 below shows the hypothesis testing of $\mathrm{H} 1, \mathrm{H} 2$ and $\mathrm{H} 3$. 
INTERNATIONAL JOURNAL OF ACADEMIC RESEARCH ECONOMICS AND MANAGEMENT SCIENCES

Vol. 10, No. 1, 2021, E-ISSN: 2226-3624 ㄷ 2021 HRMARS

Table 6: Hypothesis testing ( $\mathrm{H} 1, \mathrm{H} 2$ and $\mathrm{H} 3)$

\begin{tabular}{|c|c|c|c|c|c|c|}
\hline Hypothesis & Relationship & $\begin{array}{l}\text { Std } \\
\text { Beta( } \beta)\end{array}$ & $\begin{array}{l}\mathrm{t}- \\
\text { value* }\end{array}$ & Decision & $\mathbf{R}^{2}$ & f2 \\
\hline $\mathrm{H} 1 \mathrm{a}$ & $\begin{array}{l}\text { Brand Reputation } \rightarrow \\
\text { Commitment }\end{array}$ & 0.382 & 6.455 & Accepted & 0.482 & 0.160 \\
\hline $\mathrm{H} 1 \mathrm{~b}$ & Brand Reputation $\rightarrow$ Trust & 0.327 & 6.116 & Accepted & & 0.123 \\
\hline $\mathrm{H} 2 \mathrm{a}$ & $\begin{array}{l}\text { Alternative Attractiveness } \\
\rightarrow \text { Commitment }\end{array}$ & 0.380 & 7.022 & Accepted & & $0.15 \varepsilon$ \\
\hline $\mathrm{H} 2 \mathrm{~b}$ & $\begin{array}{l}\text { Alternative Attractiveness } \\
\rightarrow \text { Trust }\end{array}$ & 0.453 & 9.116 & Accepted & 0.508 & $0.23 \epsilon$ \\
\hline H3a & $\begin{array}{l}\text { Commitment } \rightarrow \text { Customer } \\
\text { Loyalty }\end{array}$ & 0.443 & 7.942 & Accepted & & 0.184 \\
\hline $\mathrm{H} 3 \mathrm{~b}$ & Trust $\rightarrow$ Customer Loyalty & 0.330 & 5.642 & Accepted & 0.523 & 0.102 \\
\hline
\end{tabular}

$* \mathrm{P}<0.05$

Relationship between RMT's And Customer Loyalty with the Addition of Mediating Variables (H4a, H4b, H4c, And H4d)

The relationship between brand reputation and customer loyalty with the presence of commitment as mediating variable (hypothesis $\mathrm{H} 4 \mathrm{a}$ ), produced $\mathrm{B}=.1129, \mathrm{Cl}=.0601$ to .1715 , meanwhile, the relationship between Brand Reputation and Customer Loyalty, with the presence of Trust as mediating variable (hypotheses $4 c$ ) shown $\mathrm{B}=.1963, \mathrm{Cl}=.1316$ to .2680 . This result has confirmed the mediating role of relationship quality in the relationship between Brand Reputation and Customer Loyalty since zero falls outside of the interval (Strout \& Bolger, 2002; Preacher \& Hayes, 2008; Preacher \& Hayes, 2009; Blaauw, 2012). Since path c' shown that Brand Reputation was significantly related with Customer Loyalty $B=.3101, p<.001$, therefore the relationship suggests a partial mediation (Baron \& Kenny, 1986; Strout \& Bolger, 2002; Preacher \& Hayes, 2004; 2008). Accordingly, hypotheses $\mathrm{H} 4 \mathrm{a}$ and $\mathrm{H} 4 \mathrm{C}$ are supported in this study. Bootstrapping result in Table 7 shown the relationship for brand reputation. 
INTERNATIONAL JOURNAL OF ACADEMIC RESEARCH ECONOMICS AND MANAGEMENT SCIENCES Vol. 10, No. 1, 2021, E-ISSN: 2226-3624 ㄷ 2021 HRMARS

Table 7: Mediation effect ( $\mathrm{H} 4 \mathrm{a}$ and $\mathrm{H} 4 \mathrm{c}$ )

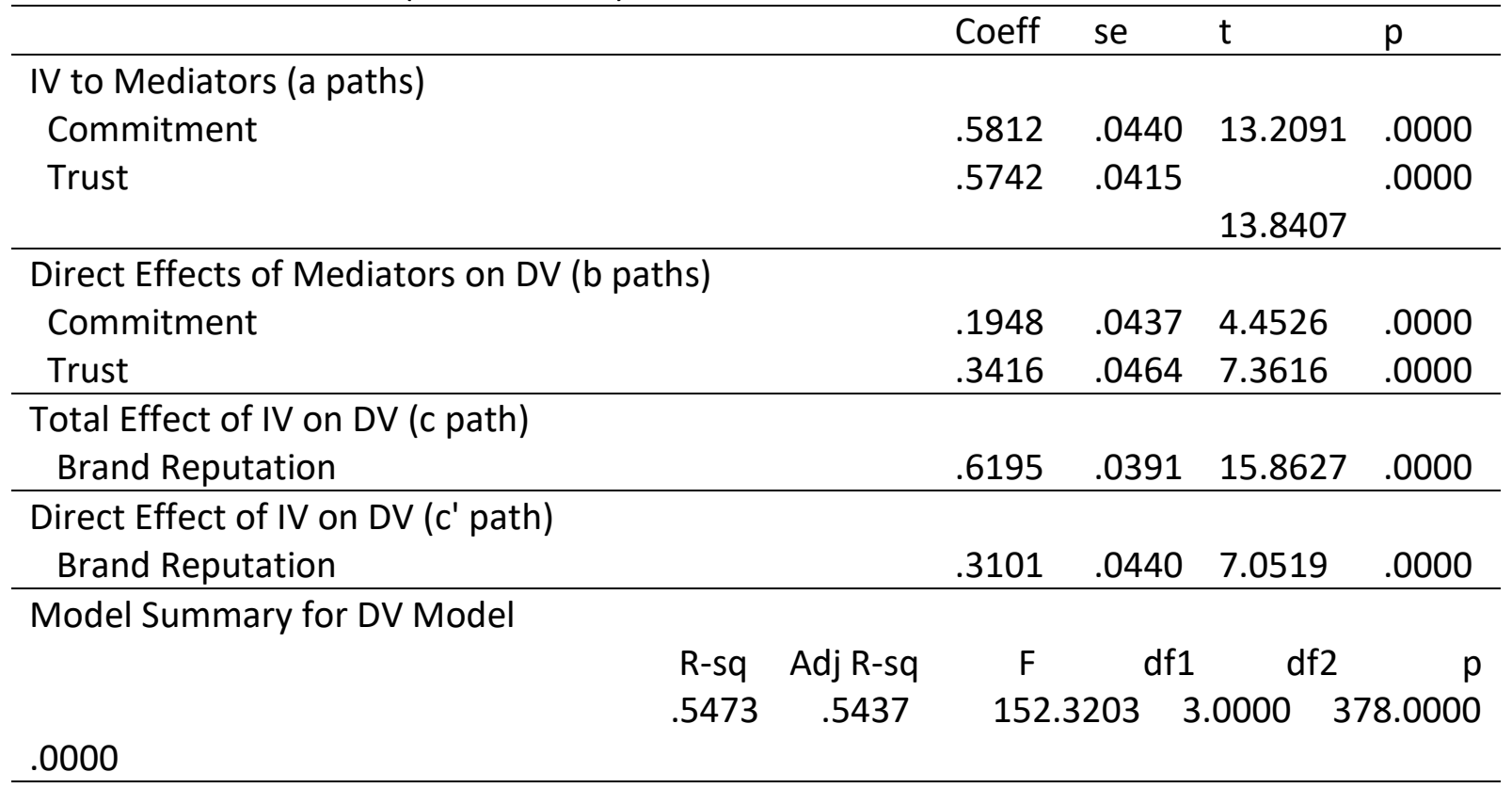

BOOTSTRAP RESULTS FOR INDIRECT EFFECTS

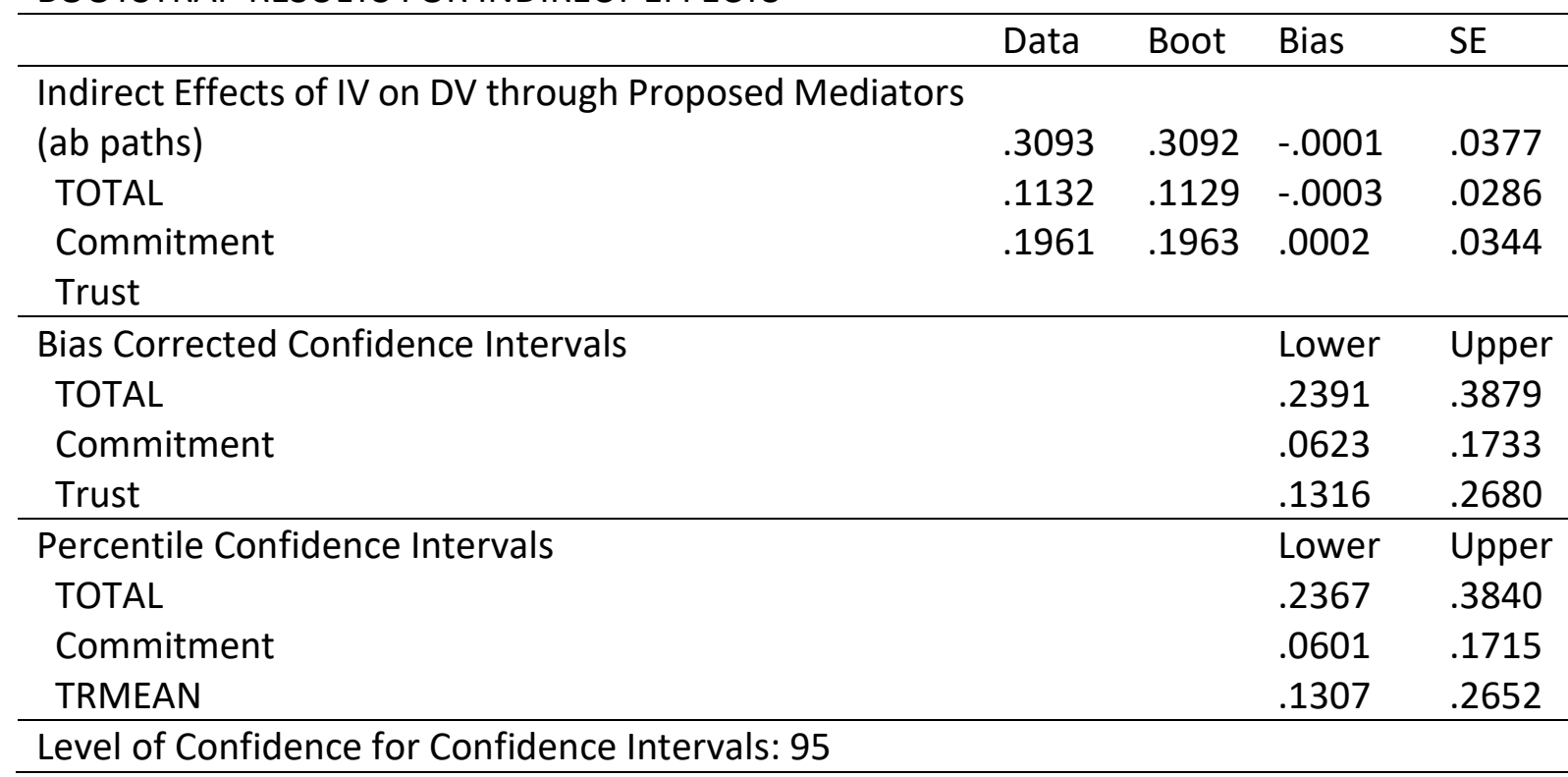

a. Dependent Variable: Commitment

b. Independent Variable: Brand Reputation

c. Mediating Variable: Commitment, Trust

The relationship between alternative attractiveness and customer loyalty, with the presence of mediating variable, commitment (Hypotheses $\mathrm{H} 4 \mathrm{~b}$ ) shown $\mathrm{B}=.1304, \mathrm{Cl}=.0801$ to .1910 , meanwhile, the relationship between alternative attractiveness and customer loyalty, with the presence of trust as mediating variable (hypothesis $\mathrm{H} 4 \mathrm{~d}$ ) produced $\mathrm{B}=.2111, \mathrm{Cl}=.1434$ to .2887 . Since zero does not occur between lower boundary confidence interval and upper boundary 
confidence interval, the indirect effect for this mediation can be assumed as significant (Strout \& Bolger, 2002; Preacher \& Hayes, 2008; Preacher \& Hayes, 2009; Blaauw, 2012). Furthermore, the results from path $c^{\prime}$ shows that alternative attractiveness was significantly related with Customer Loyalty $B=.2644, p<.001$, suggesting a partial mediation in the relationship (Strout \& Bolger, 2002; Preacher \& Hayes, 2004; 2008). Therefore, hypotheses H4b and H4d are supported in this study. Meanwhile, Table 8 shows the results of bootstrapping analysis for alternative attractiveness

Table 8: Mediation effect ( $\mathrm{H} 4 \mathrm{~b}$ and $\mathrm{H} 4 \mathrm{~d})$

\begin{tabular}{|c|c|c|c|c|c|c|}
\hline & & & Coeff & se & $\mathrm{t}$ & $p$ \\
\hline \multicolumn{7}{|l|}{ IV to Mediators (a paths) } \\
\hline \multicolumn{3}{|l|}{ Commitment } & .5603 & .0466 & 12.0182 & .0000 \\
\hline \multicolumn{3}{|l|}{ Trust } & 6180 & .0418 & 14.8014 & .0000 \\
\hline \multicolumn{7}{|c|}{ Direct Effects of Mediators on DV (b paths) } \\
\hline \multicolumn{3}{|c|}{ Commitment } & .2324 & .0436 & 5.3272 & .0000 \\
\hline \multicolumn{3}{|l|}{ Trust } & .3421 & .0487 & 7.0230 & .0000 \\
\hline \multicolumn{7}{|l|}{ Total Effect of IV on DV (c path) } \\
\hline \multicolumn{3}{|l|}{ Alternative Attractiveness } & .6061 & .0415 & 14.5923 & .0000 \\
\hline \multicolumn{7}{|c|}{ Direct Effect of IV on DV (c' path) } \\
\hline \multicolumn{3}{|c|}{ Alternative Attractiveness } & .2644 & .0463 & 5.7145 & .0000 \\
\hline \multicolumn{7}{|l|}{ Model Summary for DV Model } \\
\hline \multirow{2}{*}{ 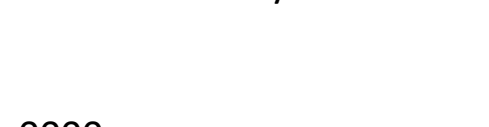 } & $\mathrm{R}-\mathrm{sq}$ & Adj R-sq & $\mathrm{F}$ & \multicolumn{2}{|l|}{ df1 } & $\mathrm{p}$ \\
\hline & .5285 & .5247 & 141.210 & & .00003 & 78.0000 \\
\hline .0000 & & & & & & \\
\hline
\end{tabular}

BOOTSTRAP RESULTS FOR INDIRECT EFFECTS

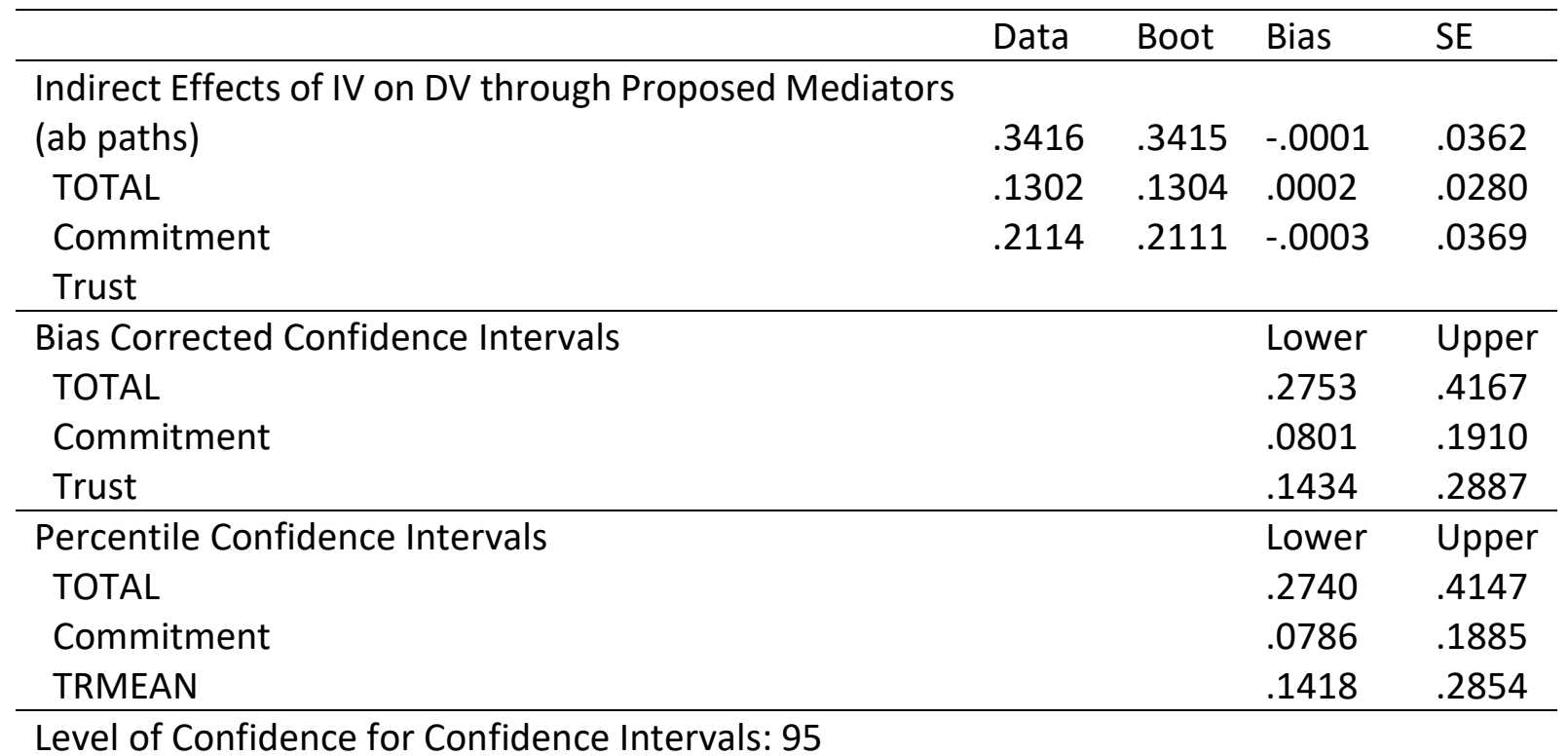

a. Dependent Variable: Customer Loyalty; b. Independent Variable: Alternative Attractiveness; c. Mediating Variable: Commitment, Trust 


\section{Discussion}

The theoretical mechanisms used to explain the conceptual framework and research hypotheses are derived from two different sources. First, the principle of Push-Pull-Mooring Migration Model by Bansal et.al, (2005) was explored to explain the effects of the relationship marketing tactics on customer loyalty. Second, the theoretical concept of Commitment-Trust Relationship Marketing Theory by Morgan \& Hunt (1994) was used to explain the impact of proposed mediating variables in the relationship between the RMT and customer loyalty. The study focuses on customers' perception towards their service providers' RMT, which may affect their intention to consider alternative service providers and whether to switch or remain loyal to the existing ones.

A major finding of this study is the empirical identification of potential relationship marketing tactics (RMT) that enable Malaysian mobile service providers to either develop or strengthen their tactics in an attempt to retain their customers. The results indicate that brand reputation and alternative attractiveness have significantly affected the customers' decision towards selecting a mobile service provider. Besides, this finding also provides an early warning for the concerned service providers to further improve on their products and services' brand image, as well as provide better add-on valued services in ensuring a continued customer retention and subsequently customer loyalty.

Further findings reveal that brand reputation is the most influential factor to be considered by the mobile service providers. Most of the mobile users have a tendency to stay loyal with a provider who offers more attractive features such as better service package, lower price, wider mobile coverage, and an excellent after-sales services, and consistent updates from their service providers. Failure to provide such attractive product features will lead the customers to look elsewhere for other alternative offers by competitors, thus resulting in switching behaviour.

This study also discerns the importance of relationship quality on customer loyalty. Commitment and trust are found to be significantly associated with customer loyalty. This is harmonious with the findings from the previous research (e.g. Akrout \& Nagy, 2018; Sheth, 2017; Ghasemi et.al, 2010), which suggest that the higher the level of commitment and trust perceived by the customers, the higher the level of customer loyalty achieved by the service providers. In addition, results from the mediation analyses also successfully demonstrate that relationship quality has mediating effects within the relationship between RMT's and customer loyalty.

\section{Conclusion}

This study has identified some limitations that need to be investigated in future research. Firstly, this study was developed to extend a theoretical model which is originally based from Bansal et.al. (2005). However, this study did not focus on all of variables derived. Future studies could apply other variables in the model to more meaningful manners. For example, various factors from 'Push Effect' needs to be introduced as the relationship marketing tactics (RMT) as suggested by Bansal et.al, (2005). Secondly, this study only analysed the relationship between the relationship marketing tactics (RMT) and relationship quality (RQ) on customer loyalty; given the relationship quality are Commitment and Trust. Future study could explore other dimensions of $R Q$ such as satisfaction and communication. 
INTERNATIONAL JOURNAL OF ACADEMIC RESEARCH ECONOMICS AND MANAGEMENT SCIENCES

Vol. 10, No. 1, 2021, E-ISSN: 2226-3624 @ 2021 HRMARS

\section{References}

Abdullah, M. F., Putit, L., \& Teo, C. B. C. (2014). Impact of Relationship Marketing Tactics (RMT's) \& Relationship Quality on Customer Loyalty: A Study within the Malaysian Mobile Telecommunication Industry. Procedia - Social and Behavioral Sciences, 130, 371-378.

Ahn, J., Shamim, A., \& Park, J. (2021). Impacts of cruise industry corporate social responsibility reputation on customers' loyalty: Mediating role of trust and identification. International Journal of Hospitality Management, 92, 102706. doi: 10.1016/j.ijhm.2020.102706

Andersson, P., \& Karlström, K. (2014). Factors Influencing a Customer's Loyalty in B2B Relationships: A Qualitative Study of Relationship Marketing. (Master's Program in International Marketing), Halmstad University.

Akrout, H. \& Nagy, G. (2018). Trust and commitment within a virtual brand community: The mediating role of brand relationship quality. Information \& Management. Vol. 55 (8). December 2018, Pp. 939-955

Aydin, S., \& Özer, G. (2005). The Analysis of Antecedents of Customer Loyalty in the Turkish Mobile Telecommunication Market. European Journal of Marketing, 39(7/8), 910-925.

Bansal, H. S., Taylor, S. F., \& James, Y. S. (2005). "Migrating" to New Service Providers: Toward a Unifying Framework of Consumers' Switching Behaviors. Journal of the Academy of Marketing Science, 33(1), 96-115.

Baron, R., \& Kenny, D. (1986). The moderator-mediator variable distinction in social psychological research: Conceptual, strategic and statistical considerations. Journal of Personality and Social Psychology, 51, 1173-1182. DOI: PMID: 3806354

Bashir, N. H. (2011). An Application of the Push-Pull-Mooring Model within the Mobile Service Sector in Kuwait. Master of Business Administration (MBA), Maastricht School of Management (MSM), Maastricht, Netherland.

Bernard, H. R. (2000). Social research methods: Qualitative and quantitative approaches. Thousand Oaks, CA: Sage Publications.

Bianchi, C., \& Abu Saleh, M. (2020). Investigating SME importer-foreign supplier relationship trust and commitment. Journal of Business Research, 119, 572-584. doi: 10.1016/j.jbusres.2020.07.023

Blaauw, J. (2012). Behavioral Influence on Operational Performance: The Influence of Team Reflexivity on Anchoring and Adjustment Bias and Team Performance within Operations Management. (Master of Science Business Administration), Eramus University. (351116)

Cheng, T. C. E., Lai, I. C. F., \& Yeung, A. C. L. (2008). The Driving Forces of Customer Loyalty: A Study of Internet Service Providers in Hong Kong. International Journal of E-Business Research, 4(4), 26-42.

Churchill, G. A. Jr., \& lacobucci, D. (2005). Marketing Research: Methodological Foundations. 9th Ed., United States: Thomson / South-Western.

Cooper, C. (2002). The Role of Commitment in Relationship Marketing in Consumer Services - an Airline Perspective. Master of Philosophy, Dublin Institute of Technology.

Dithan, N. P. (2011). Relationship Marketing, Word of Mouth Communication and Customer Loyalty in the Telecommunication Industry of Uganda. Master of Science in Marketing, Makerere University, Kampala, Uganda. 
Foroudi, P. (2019). Influence of brand signature, brand awareness, brand attitude, brand reputation on hotel industry's brand performance. International Journal of Hospitality Management, 76, 271-285. doi: 10.1016/j.ijhm.2018.05.016

Ghasemi, S., Hashemi, R., \& Navid, B. (2013). A Study of the Relationship between Relationship Marketing Tactics and Conflict Management with Customer Loyalty in the Private Banks in Kermanshah. International Research Journal of Applied and Basic Sciences, 5(2), 214220.

Gholami, R., Sulaiman, A. B., Ramayah, T., \& Molla, A. (2013). Senior managers' perception on green information systems (IS) adoption and environmental performance: Results from a field survey. Information \& Management, 50(7), 431-438.

Hennig-Thurau, T., Gwinner, K. P., \& Gremler, D. D. (2002). Understanding the Relationship Outcomes: An Integration of Relational Benefits and Relationship Quality.Journal of Service Research, 4(3), 230-247.

Jesri, P., Ahmadi, F., \& Fatehipoor, M. (2013). Effects of Relationship Marketing on Customer Loyalty (Case Study: Mehr Bank, Kermanshah Province, Iran). Interdisplinary Journal of Contemporary Research in Business, 4(11), 304-312.

Kazemifar, H., \& Shayesteh, J. (2015). The Impact of Relationship Marketing Tactics on Customer Loyalty: Iranian Mobile Operators. (Master in Business Administration), Luleå University of Technology.

Krejcie, R. V., \& Morgan, D. (1970). Determining Sample Size for Research Activities. Educational \& Psychological Measurement, 30, 607-610.

Leverin, A., \& Liljander, V. (2006). Does Relationship Marketing Improve Customer Relationship Satisfaction and Loyalty? International Journal of Bank Marketing, 24(4), 232-251.

Malhotra, N. K. (2009), Marketing Research: An Applied Orientation, 6th Edition

Mannan, M., Mohiuddin, M. F., Chowdhury, N., \& Sarker, P. (2017). Customer satisfaction, switching intentions, perceived switching costs, and perceived alternative attractiveness in Bangladesh mobile telecommunications market. South Asian Journal of Business Studies, 6(2), 142-160. doi: 10.1108/sajbs-06-2016-0049

Morgan, R. M., \& Hunt, S. D. (1994). The Commitment -Trust Theory of Relationship Marketing.Journal of Marketing, 58, 20-38.

Naudé, P., \& Buttle, F. (2000). Assessing Relationship Quality.Industrial Marketing Management, 29(4), 351-361.

Nikbin, D., Ismail, I., \& Marimuthu, M. (2012). Perceived Justice in Service Recovery and Switching Intention: Evidence from Malaysian Mobile Telecommunication Industry. Management Research Review, 35(3/4), 309-325.

Palmatier, R. W. (2008). Relationship Marketing (Vol. 1). Marketing Science Institute, Cambridge, Massachusetts.

Peng, L. Y. (2006). Relationship Marketing in Building Customer Retention, Acquisition and Loyalty in a Competitive Service Industry. Doctor of Philosophy in Industrial and Business Studies, Warwick Business School, University of Warwick.

Peng, L. Y., \& Wang, Q. (2006). Impact of Relationship Marketing Tactics (RMT's) on Switchers and Stayers in a Competitive Service Industry. Journal of Marketing Management, 44, 2259. 
Peng, L. Y., \& Wang, Q. (2007). Effects of Customer Beliefs on Relationship Marketing Tactics and Customer Attitude on Switching Intention in a Competitive Service Industry. Advances in Consumer Research VII, 294-304.

Preacher, K. J., and Hayes, A. F. (2004). "SPSS and SAS procedures for estimating indirect effects in simple mediation models." Behavior Research Methods, Instruments, \& Computers 36(4).

Preacher, K. J., \& Hayes, A. F. (2008). Contemporary approaches to assessing mediation in communication research. The Sage. (pp. 13-54). Thousand Oaks, CA: Sage.

Putit, L., \& Abdullah, F. (2019) Exploring Relationship Marketing Tactics \& Customer Loyalty: Issues in the Malaysian Telecommunication Sector. Journal of International Business, Economics and Entrepreneurship Volume 4, (1), 21-26. ISSN :2550-1429

Rahman, M. A., \& Ramli, M. F. (2016). The Influence of Relationship Quality on Customer Loyalty in the Dual-Banking System in the Northern States of Peninsular Malaysia. Procedia Social and Behavioral Sciences, 219, 606-613. doi: 10.1016/j.sbspro.2016.05.040

Reydet, S., \& Carsana, L. (2017). The effect of digital design in retail banking on customers' commitment and loyalty: The mediating role of positive affect. Journal of Retailing and Consumer Services, 37, 132-138. doi: 10.1016/j.jretconser.2017.04.003

Ryan, J., \& Casidy, R. (2018). The role of brand reputation in organic food consumption: A behavioral reasoning perspective. Journal of Retailing and Consumer Services, 41, 239247. doi: 10.1016/j.jretconser.2018.01.002

Sengupta, S. A., Balaji, M. S., \& Krishnan, B. C. (2015). How customers cope with service failure? A study of brand reputation and customer satisfaction. Journal of Business Research, 68(3), 665-674. doi: 10.1016/j.jbusres.2014.08.005

Sharma, N., \& Patterson, P. G. (2000). Switching costs, alternative attractiveness and experience as moderators of relationship commitment in professional, consumer services. International Journal of Service Industry Management, 11(5), 470-490.

Sheth, J. (2017). Revitalizing relationship marketing. Journal of Services Marketing, Vol. 31 No. 1, pp. 6-10. https://doi.org/10.1108/JSM-11-2016-0397

Shrout, P. E., \& Bolger, N. (2002). Mediation in experimental and non-experimental studies: New procedures and recommendations. Psychological Methods, 7, 422-445.

Tseng, Y. M. (2007). The Impact of Relationship Marketing Tactics on Relationship Quality in Service Industry. The Business Review, Cambridge 7(2), 310-314.

Van Tonder, E (2017). Trust and Commitment As Mediators Of The Relationship Between Quality Advice And Customer Loyalty, Journal of Applied Business Research, Vol. 32(1). Pp 289302.

Yen, Y.-X., \& Horng, D.-J. (2010). Effects of Satisfaction, Trust and Alternative Attractiveness on Switching Intentions in Industrial Customers. International Journal of Management and Enterprise Development, 8(1). 